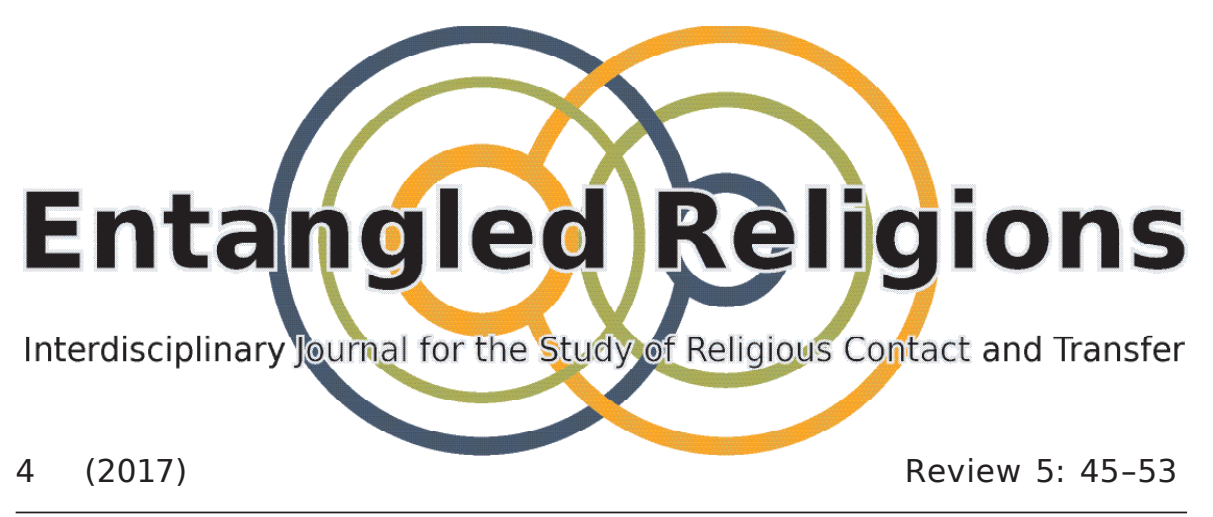

\title{
Religious Diversity. Philosophical and Political Dimensions
}

\section{By Roger Trigg.}

Cambridge Studies in Religion, Philosophy, and Society, IX.

New York: Cambridge University Press, 2014.

199 pages (incl. Bibliography and Index),

\$29,99, ISBN: 9781107638778 (paperback)

REVIEW BY: SARAH J. JAHN

Center for Religious Studies, Ruhr-Universität Bochum, Germany

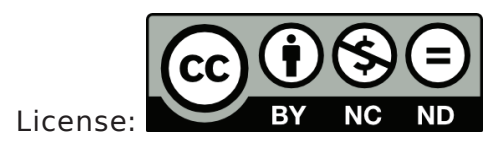

This contribution to Entangled Religions is published under the Creative Commons Attribution-NonCommercial-NoDerivatives 4.0 International Public License (CC BY-NC-ND 4.0 International). The license can be accessed at http://creativecommons.org/licenses/ by-nc-nd/4.0/or is available from Creative Commons, 559 Nathan Abbot Way, Stanford, California 94305, USA

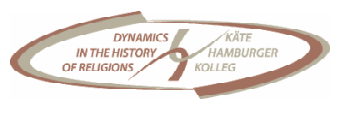




\section{Religious Diversity. Philosophical and Political Dimensions}

By Roger Trigg.

Cambridge Studies in Religion, Philosophy, and Society, IX. New York: Cambridge University Press, 2014.

199 pages (incl. Bibliography and Index), $\$ 29,99$, ISBN: 9781107638778 (paperback)

REVIEW BY: SARAH J. JAHN

Ruhr-Universität Bochum

Religious diversity is a timely topic. In the social sciences, manifold studies research how religious plurality becomes manifest and how religious diversity is regulated in the public sphere. They often address so called Western countries and have a local focus as single or collaborative case studies. ${ }^{1}$ Drawing from both earlier and newer studies (e.g. Trigg 1973, 1993, 2007, 2012), Roger Trigg also focuses on the question of how religious diversity affects Western countries, but not on an empirical level. He discusses "the underlying philosophical issues of how religion, and religious differences, is to be understood" (2). Furthermore, he raises questions with political dimensions, such as, "how can people with different religious beliefs, and none, live together, without the conflict that seems only too evident in many parts of the contemporary world?" (ibid.). The reviewed book is explicitly introduced as presenting a normative way of thinking,

1 An overview of some local and collaborative projects is given in the Plureligion Network. 2016. Projects, last accessed 16/08/2016: http://plureligion.net/en/information. 
and as such it is an enrichment for scholars who deal empirically with questions of religious diversity in so called Western societies to broaden the disciplinary perspective. But from my social scientific point of view as reviewer, such a substantive understanding of religion and normative use of terms like democracy and freedom is not an option when discussing religious diversity academically. However, for scholars with deeper insights into the topic some questions remain open. In his historical and political examples, it seems that Trigg mainly addresses the case of Great Britain and North America - not only regarding sources and contexts, but also cited scholarly positions. Including other so called Western societies in nonreligious and Catholic settings or other understandings of religious freedom would have enriched the discussion about religious diversity as challenge.

\section{Executive Summary}

Most of the ten chapters serve as a thought experiment with a simple question as starting point, divided into different fragments to treat the question. These fragments contain references to the Philosophy of Religion, Social Philosophy, the Social Sciences, Sociobiology, historical and political cases, et cetera. The book is well written and structured and serves as a compendium of ten essays, building on historical and political examples as well as historical and contemporary positions in Philosophy and the Social Sciences. As such it is an interdisciplinary and comprehensive source to use in university courses.

Chapter one deals with "The Challenge of Religious Diversity" and grounds the overall topic in a philosophical way. "Challenge" addresses emerging problems for individuals and society, the different ways of 
understanding religious freedom as a historical category within society, legal texts and religious traditions, as well as normative concerns of democratic diversities, subjective religion, and concepts of truth in religious traditions (18-22).

The following four chapters go into more detail to outline the philosophical dimension: Trigg starts with the question of “Does Religions Claim Truth?" (Chapter two). With reference to Peter Berger and Anton Zijderveld (2009), Trigg points out that we must distinguish between relativist and realist views and pluralism. Pluralism, according to Peter Berger and Anton Zijderveld, "is the attitude, possibly expanded into a full-blown philosophy, that welcomes the reality" (24) which is plurality. Plurality therefore is a sociological term which describes the social reality of many religions as part of one society. To negotiate plurality, one major option is to relate differences. But relativism leads to ethnocentrism and realism to authoritarianism, Trigg argues (28-30). As an alternative perspective, he introduces Ludwig Wittgenstein's work on language and context (Wittgenstein 1966). Wittgenstein emphasizes the specific context of language. His positivist view states that there is no objective, given reality and different lingusitic meanings can be put in relation to one another. From his perspective, "divine reality" is possible in "Religious Pluralism" (Chapter three). This understanding raises the question on which basis religious contact takes place when everyone has his or her own reality. Trigg states: "To enter into any dialogue, we all have to be situated in the same reality" (59). One common ground could be "the Roots of Religious Belief" (Chapter four). When discussing epistemological positions of Sociobiology and the Cognitive Science of Religion, Trigg states that "diversity is not just a matter of superficial variation of an underlying similarity. The differences between religions will always go much deeper than that" (73). Furthermore, "religious diversity is not superficial .... The 
different superstructures built on the same foundations are each of very great significance" (74). Understanding religious diversity as the existence of parallel superstructures in one society, he argues, one may ask whether these superstructures clash and thus, in consequence, "Disagreement Undermines Theism" (Chapter five). Besides taking this view on diversity, Trigg follows Miller $(2012,9)$ in arguing that in historical thinking religious ideas can be seen as drivers of history, if 'religion' is perceived as a social and cultural phenomenon (92). Therefore, "religious diversity may give more scope for exercising human freedom and be a consequence of that freedom" (83). But this philosophical claim of equal truths of all religions clashes with political realities, Trigg states.

Departing from this conclusion, the next four chapters outline the more political dimension of diversity. Chapter six deals with the topic of "Education and Religious Diversity". The challenge of pluralist societies is that they respond to the "equality dilemma" with a secular approach that does not grant religion a place in the public sphere. For instance, religion in public schools may not be taught as "truth" but as a social phenomenon with a focus on aspects of practice and history instead of on religious justification (99). But the consequence is that "religion is trivialized when claims to truth are substracted" (ibid.), Trigg argues. There are different consequences in Western societies to govern this dilemma, including Canada, which practices the Toledo Principles (Office for Democratic Institutions and Human Rights 2007), and France, with no religious education in public schools (111). In this understanding, not religion is a value but religious freedom and diversity (108). Therefore religious freedom is the new truth and religious values must be part of the private sphere. This raises the question of how identity building takes place when no religious values are part of public identity. Here, Trigg highlights the role of institutions, on the one hand, because institutions are "buffers 
between the individual and the state" (135). But on the other, he mentions that human rights are individual rights and no religious institutions have to claim truth in an open and democratic society.

Ultimate freedom, in practice, means that everyone can choose his or her religious identity, beliefs, and membership. "Religion as Personal Preference" (Chapter nine) in secular societies is an object of interest in rational choice theory (Stark and Bainbridge 1985). Rational choice theory has been applied for analysing religious institutions in the public sphere where one religion has no central role for identity building and religious freedom is part of the legal system. As such, one core idea is that personal preferences are rational decisions. Martha Nussbaum (2008) is one of the critiques of rational choice theory. She criticises the 'missing truth' and subjective view on religion in rational choice theory. She mentions that religion can be seen as vigor in the sense of "flourishing of religion", and diversity could be product of vigor (158-162). Coming back to the subjective perspective, the Trigg's thought experiment starts once again with the question of truth.

However, all these tensions, dilemmas, and questions regarding religious diversity culminate in the relation between "Freedom and Religion" (Chapter ten), Trigg argues. In the context of human rights, he raises the question whether religious diversity presents a special case. Canadian Communitarians Maclure and Taylor $(2011,10)$ write that religious diversity is "an aspect of the phenomenon of 'moral pluralism' with which contemporary democracies have to come to terms" (170). Along these lines, Trigg states that "religion has a political relevance ... because it can contribute to public debate concerning what constitutes human welfare and harm. [...] All societies need basic animating principles, but the belief in freedom has to be basic" (186). This is his key message and philosophical 
assumption in understanding and regulating religious diversity on a political level.

\section{Critical Acclaim}

As already stated in the introduction, a number of prominent academic positions are missing and the religious-cultural perspective could be describe as narrow. To get an idea of dealing with and thinking about religious diversity in different ways, other positions and religious-cultural contexts would be of interest. To mention only two international well-known positions, the classical Habermas position emphasizes the conditions for and results of religious institutions taking part in the public sphere (Habermas 2006). Sullivan's (2007) work on the specifically North American context is also missing. Sullivan studied precisely the relation between the normative frameworks of law and religions, but comes to another conclusion, arguing that religious freedom is not possible in secular societies. The preferred religious-cultural context aside, an outlook on "multiple secularities" (Burchardt, Wohlrab-Sahr, and Wegert 2013) or on societies with legal pluralism would have been innovative (Bender-Beckmann 2009). Within this perspective, countries in Asia, such as India and Indonesia, but also European ones like the Netherlands would be of interest. This would result in a broader perspective on historical, political, and philosophical sources and cases, but also in cross-cultural thinking about historical and cultural societies rooted in Christianity, in science, and in political systems in order to reveal the influence of religious contacts and transfer on religious diversity. 


\section{Reference List}

Benda-Beckmann, Keebet von. 2009. "Balancing Islam, Adat and the State: Comparing Islamic and Civil Courts in Indonesia." In The Power of Law in a Transnational World: Anthropological Enquiries, edited by Keebet von Benda-Beckmann, Franz von BendaBeckmann, and Anne Griffiths, 216-235. New York: Berghahn Books.

Berger, Peter, and Anton Zijderveld. 2009. In Praise of Doubt. New York: HarperOne.

Burchardt, Marian; Monika Wohlrab-Sahr, and Ute Wegert. 2013. “'Multiple secularities': Postcolonial variations and guiding ideas in India and South Africa." International Sociology 28 (6): 612628.

Habermas, Jürgen. 2006. "Pre-political Foundation of the Democratic Constitutional State." In Dialectics of Secularization: On Reason and Religion, edited by Jürgen Habermas, Pope Benedict, and Florian Schuller, 19-52. San Francisco: Ignatius Press.

Macclure, Jocely, and Charles Taylor. 2011. Secularism and Freedom of Conscience. Cambridge, MA: Harvard University Press.

Miller, Nicholas P. 2012. The Religious Roots of the First Ammendment: Dissenting Protestants and the Separation of Church and State. New York: Oxford University Press.

Nussbaum, Marta. 2008. Liberty of Conscience: In Defense of America's Tradition of Religious Equality. New York: Basic Books.

Office for Democratic Institutions and Human Rights, ed. 2007. Toledo Guiding Principles on Teaching about Religions and Beliefs in Public Schools. Accessed August 15, 2016. http://www.osce.org/ odihr/29154?download=true. 
Stark, Roger, and William S. Bainbridge. 1985. The Future of Religion. Berkeley: University of California Press.

Sullivan, Winnifred F. 2007. The Impossibility of Religious Freedom. Princeton, New York: Princeton University Press.

Trigg, Roger. 1973. Reason and Commitment. Cambridge: University Press.

Trigg, Roger. 1993. Rationality and Science: Can Science Explain Everything? Oxford: Blackwell.

Trigg, Roger. 2007. Religion in Public Life: Must Faith be Privatized? Oxford: University Press.

Trigg, Roger. 2012. Equality, Freedom, and Religion. Oxford: University Press.

Wittgenstein, Ludwig. 1966. Lectures and Conversations on Aestethics, Psychology and Religious Belief. Edited by Cyril Barrett. Oxford: Blackwell. 